This item was submitted to Loughborough's Research Repository by the author.

Items in Figshare are protected by copyright, with all rights reserved, unless otherwise indicated.

\title{
Global media cities in transnational media networks
}

PLEASE CITE THE PUBLISHED VERSION

http://dx.doi.org/10.1111/j.1467-9663.2012.00738.x

\section{PUBLISHER}

Blackwell Publishing Ltd. on behalf of the Royal Dutch Geographical Society KNAG (@ 2012 The Authors)

\section{VERSION}

AM (Accepted Manuscript)

\section{LICENCE}

CC BY-NC-ND 4.0

\section{REPOSITORY RECORD}

Hoyler, Michael, and Allan Watson. 2019. "Global Media Cities in Transnational Media Networks". figshare. https://hdl.handle.net/2134/12350. 
This item was submitted to Loughborough's Institutional Repository (https://dspace.lboro.ac.uk/) by the author and is made available under the following Creative Commons Licence conditions.

\section{creative
commons}

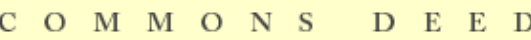

Attribution-NonCommercial-NoDerivs 2.5

You are free:

- to copy, distribute, display, and perform the work

Under the following conditions:

Attribution. You must attribute the work in the manner specified b the author or licensor.

Noncommercial. You may not use this work for commercial purposes.

No Derivative Works. You may not alter, transform, or build upon this work.

- For any reuse or distribution, you must make clear to others the license terms of this work.

- Any of these conditions can be waived if you get permission from the copyright holder.

Your fair use and other rights are in no way affected by the above.

This is a human-readable summary of the Leqal Code (the full license).

\section{Disclaimer 만}

For the full text of this licence, please go to: http://creativecommons.org/licenses/by-nc-nd/2.5/ 


\title{
Global media cities in transnational media networks
}

\author{
Michael Hoyler* and Allan Watson** \\ 'Department of Geography, Loughborough University, Loughborough, \\ Leicestershire, LE11 3TU, UK. E-mail: M.Hoyler@lboro.ac.uk \\ **Department of Geography, Staffordshire University, Stoke-on-Trent, \\ Staffordshire, ST4 2DF, UK. E-mail: A. Watson@staffs.ac.uk
}

\begin{abstract}
This paper considers an alternative dimension of world city network formation, driven by transnational media corporations rather than advanced producer services. Through an empirical analysis of the office networks of leading media corporations, the paper measures the integration of global media cities into the world city network in 2011. An interlocking network model is employed to determine the connectedness of cities within media networks, and a principal components analysis used to identify six media fields that represent the locational strategies of transnational media corporations. The results highlight the regionality of global corporate media strategies, which are firmly anchored in the major home markets of North America, Europe and Japan but reach out to other world regions through strategically positioned media cities.
\end{abstract}

\section{Key Words}

Global media city, transnational media corporations, world city network, global media networks, principal components analysis, interlocking network 


\section{Introduction}

While world cities research has often focused on the role of advanced producer services in linking city economies across different scales (e.g. Taylor 2004; Hoyler et al. 2008; Taylor et al. 2011), it is clear that global networking processes involve a much wider variety of economic activities. As Krätke and Taylor (2004, p. 459) emphasise, "a diversity of globalized activities leads to multiple globalizations within world city network formation". This paper is concerned with one specific dimension of globalising activities, those undertaken by transnational media corporations (TNMCs). TNMCs are now amongst the largest firms in the world, providing economic and cultural networks that extend throughout the global urban system. Globalisation, deregulation and digitisation have removed many of the limits to corporate media expansion, leading to the rapid growth of the global commercial media market (Warf 2007; Castells 2009). Giant media organisations have become central to the development of a communications infrastructure that facilitates transnational flows of information and cross-border commercial activities. The ability of TNMCs to network across distance has been significantly enhanced by the Internet, which has enabled media corporations to compete in a potentially global market space (Flew 2007).

The aim of this paper is to provide an empirical analysis of the level of integration of cities into the corporate networks of the transnational media. Apart from the pioneering work by Krätke (2002, 2003, 2006; Krätke \& Taylor 2004), there has been an empirical deficit in work on the emerging global urban geographies of media corporations. This study analyses new data on the locational 
strategies of the leading TNMCs in 2011 to assess the degree of globality of the so-called 'global media'. The empirical analysis is presented in two parts. First, an 'interlocking network' model is applied to a data matrix consisting of 24 TNMCs in 526 cities to measure the network connectivity of cities within the corporate urban networks of TNMCs. Second, a principal components analysis is employed to identify a set of six global media fields, articulated through particular key cities, which represent groups of TNMCs employing similar strategies when locating their offices in cities across the globe. The findings are contextualised within the literature on TNMCs and a first interpretation is provided of the current spatial configuration of global media networks uncovered in the analysis.

\section{The Rise of Transnational Media Corporations}

Throughout the 1990s, an unprecedented wave of mergers and acquisitions took place among media corporations. Concentration and conglomeration gave rise to oligopolistic control by a small number of very large TNMCs (Warf 2007), which have built up a significant economic and cultural presence on nearly every continent (Held et al. 1999). Increasing digitisation of content and the convergence of media and technology have led TNMCs to expand their interests across a variety of media, information and telecommunications sectors (Flew 2005). These include television and satellite, radio and music, film, print, Internet and others, which are vertically integrated in the leading media corporations to enhance their ability to distribute cultural products widely across a variety of platforms (Arsenault \& Castells 2008a). Furthermore, all have their own global distribution networks (McChesney 1998). Table 1 shows the top media corporations in 2011, as 
identified in the Forbes Global 2000 list of leading companies (based on a composite score that takes into account sales, profits, assets and market value). The list is dominated by US companies (19 of 42), followed by the UK (5), France (3) and Japan (3).

Table 1: Media companies in the Forbes Global 2000 in 2011 (Sources: http://www.forbes.com, April 2011, a own research)

\begin{tabular}{|c|c|c|c|c|}
\hline $\begin{array}{l}\text { Media } \\
\text { rank } \\
2011\end{array}$ & $\begin{array}{l}\text { Forbes } \\
\text { rank } \\
2011\end{array}$ & Company & Country & $\begin{array}{l}\text { Headquarters } \\
\text { location } \\
\text { (metropolitan } \\
\text { region) }^{\mathrm{a}}\end{array}$ \\
\hline 1 & 104 & Comcast & United States & Philadelphia \\
\hline 2 & 110 & Walt Disney* & United States & Los Angeles \\
\hline 3 & 146 & Vivendi & France & Paris \\
\hline 4 & 149 & News Corp & United States & New York \\
\hline 5 & 163 & Time Warner & United States & New York \\
\hline 6 & 286 & Time Warner Cable* & United States & New York \\
\hline 7 & 314 & Directv & United States & Los Angeles \\
\hline 8 & 368 & Thomson Reuters & Canada & New York \\
\hline 9 & 394 & Viacom & United States & New York \\
\hline 10 & 474 & CBS $^{*}$ & United States & New York \\
\hline 11 & 511 & Reed Elsevier & United Kingdom & London \\
\hline 12 & 516 & Pearson & United Kingdom & London \\
\hline 13 & 684 & Liberty Global* & United States & Denver \\
\hline
\end{tabular}




\begin{tabular}{|c|c|c|c|c|}
\hline 14 & 685 & RTL Group & Luxembourg & Luxembourg \\
\hline 15 & 688 & $\begin{array}{l}\text { British Sky } \\
\text { Broadcasting }\end{array}$ & United Kingdom & London \\
\hline 16 & 693 & DISH Network* & United States & Denver \\
\hline 17 & 837 & Dai Nippon Printing & Japan & Tokyo \\
\hline 18 & 880 & Grupo Televisa* & Mexico & Mexico City \\
\hline 19 & 935 & McGraw-Hill Cos & United States & New York \\
\hline 20 & 992 & $\begin{array}{l}\text { Discovery } \\
\text { Communications }\end{array}$ & United States & Washington, DC \\
\hline 21 & 1016 & Cablevision* & United States & New York \\
\hline 22 & 1072 & Toppan Printing & Japan & Tokyo \\
\hline 23 & 1074 & Naspers & South Africa & Cape Town \\
\hline 24 & 1094 & SES & Luxembourg & Luxembourg \\
\hline 25 & 1153 & $\begin{array}{l}\text { Shaw } \\
\text { Communications* }\end{array}$ & Canada & Calgary \\
\hline 26 & 1182 & $\begin{array}{l}\text { Lagardère } \\
\text { Jupiter }\end{array}$ & France & Paris \\
\hline 27 & 1212 & $\begin{array}{l}\text { Telecommunications } \\
\text { * }\end{array}$ & Japan & Tokyo \\
\hline 28 & 1246 & Virgin Media* & United Kingdom & New York \\
\hline 29 & 1263 & Mediaset* & Italy & Milan \\
\hline 30 & 1279 & Nielsen Holdings & Netherlands & New York \\
\hline 31 & 1308 & Charter Commun* & United States & St Louis \\
\hline 32 & 1321 & Wolters Kluwer* & Netherlands & Amsterdam \\
\hline 33 & 1405 & $\begin{array}{l}\text { Liberty Media- } \\
\text { Capital }^{*}\end{array}$ & United States & Denver \\
\hline 34 & 1455 & $\begin{array}{l}\text { ProSiebenSat1 } \\
\text { Media* }^{*}\end{array}$ & Germany & Munich \\
\hline 35 & 1525 & Gannett* & United States & Washington, DC \\
\hline
\end{tabular}




\begin{tabular}{|c|c|c|c|c|}
\hline 36 & 1556 & CC Media Holdings & United States & San Antonio \\
\hline 37 & 1565 & $\begin{array}{l}\text { RR Donnelley \& } \\
\text { Sons }\end{array}$ & United States & Chicago \\
\hline 38 & 1585 & Scripps Networks & United States & Knoxville \\
\hline 39 & 1713 & $\begin{array}{l}\text { Eutelsat } \\
\text { Communications }\end{array}$ & France & Paris \\
\hline 40 & 1887 & ITV $^{*}$ & United Kingdom & London \\
\hline 41 & 1919 & $\begin{array}{l}\text { Modern Times } \\
\text { Group }\end{array}$ & Sweden & Stockholm \\
\hline 42 & 1985 & Axel Springer & Germany & Berlin \\
\hline
\end{tabular}

Notes: Listed are all companies in the industry categories Broadcasting \& Cable (30) and Printing \& Publishing (12)

* Excluded from analysis (headquarters information only)

The global reach of communication technologies enables media corporations to compete in a market space that is potentially worldwide in scope. However, almost no media organisation is in itself truly global and very few operate in all world markets. Rather, TNMCs tend to operate in preferred markets, particularly their home market to which they remain territorially anchored (Gershon 1997, 2000). Castells (2009, p. 72) argues that the major transformation in the media is the "formation of global networks of interlocked multimedia businesses organized around strategic partnerships". In his view, a small number of media "mega-corporations form the backbone of the global network of media networks" by connecting locally and nationally operating media firms across the globe. Chalaby (2005) suggests that media conglomerates have adopted new organisational structures, within which headquarters grant affiliates increased autonomy, 
strengthen their specialisation, and connect them into an interdependent corporate network (see also Gershon 2000). Such a strategy aims to achieve global reach and efficiency while ensuring responsiveness to the requirements of local markets. Castells (2009, p. 72) similarly argues that "only global networks can master the resources required in global media production, but their ability to conquer market shares depends on the adaptation of their content to the taste of local audiences" (see also Herman \& McChesney 1997).

For Krätke (2006, p. 326), "the trend towards cultural market differentiation is at the same time a driving force for the organization of global production networks in the culture and media industries". These networks come together in urban centres, key locations of cultural production which act as "local anchoring points" in the "cultural metropolises" of the global urban network (Krätke 2003, p. 611; Morley \& Robins 1995; Scott 2000; see also Curtin 2003, 2009 on the concept of 'media capital'). Krätke (2003) describes how TNMCs interact locally with specialist producers and service providers, linking them into their global networks of branch offices and subsidiaries. Firms in urban media clusters are therefore not only embedded locally, but also linked to firms in other cities throughout the world. These transnational linkages between media industry clusters have seen an increase in intensity over recent years and have resulted in the emergence of a system of well-connected global media cities (Krätke 2002, 2003, 2006). 


\section{Interlocking Network Model}

This paper builds methodologically and conceptually on over a decade of world city research undertaken by the Globalisation and World Cities (GaWC) research network (www.lboro.ac.uk/gawc). Although much of this research has centred on advanced producer services, following Sassen's (1991) identification of 'global cities' as key production centres and markets for business services, the research principles and methodologies developed can be applied to a wide diversity of sectors (e.g. Taylor 2005). The central tenet of GaWC research is that the organisational networks of global service providers and other firms with worldwide reach can serve as a proxy for both embodied and virtual flows that link particular sectors of city economies across space. This is the basis for the 'interlocking network model', developed to measure inter-city relations from data on intra-firm office locations (Taylor 2001).

This interlocking network for world cities is unusual in that it has three levels. At the nodal level are cities, while the net level is the global economy, consisting of all nodes and links. However, there is an additional sub-nodal level comprising of firms as the agents of world city network formation. As firms have expanded worldwide in contemporary globalisation, office networks have become central to providing a seamless service to corporate clients. It is the working flows between these offices, for example in the form of internal communications, knowledge transfer and the movement of highly-skilled people that constitute the world city network (Taylor 2004; Taylor et al. 2011). The main measure of importance in this model is network connectivity. 
Formally, the interlocking network model can be represented by a matrix $V_{i j}$ defined by $n$ firms $\times m$ cities, where $v_{i j}$ is the 'service value' (or 'media value' for TNMCs) of firm $i$ in city $j$ (Taylor 2001). This value signifies the importance of a firm's activity in a particular city and is operationalised here by assessing its local presence on a scale from 0 to 5 (see next section). Network connectivity of a city a is then defined as $N C_{a}=\sum_{i, j} v_{i a} \cdot v_{i j}(a \neq j)$. As this gross connectivity varies with the size of the matrix, network connectivities are usually expressed as proportions of the largest computed connectivity.

One advantage of using this methodological approach is that it provides a measure that allows comparison with other studies employing the interlocking network model, in particular those of global service centres linked through the office networks of advanced producer services, but also alternative networks, for example in manufacturing (Krätke 2011). In this way, specific sectoral profiles in world city network formation can be identified. Conceptually and methodologically, this approach differs from broader evaluations of corporate network structures (e.g. Alderson \& Beckfield 2004, 2012; Wall \& van der Knaap 2011). It is also less focused on the often historically determined location of command-and-control functions (i.e. headquarter locations, see Godfrey \& Zhou 1999; Taylor \& Csomós 2011) and considers the geographically wider integration of cities into strategically expanded office networks. 


\section{Data Collection}

The data used in this study were collected in the summer of 2011 to complement advanced producer services (APS) data gathered in 2010 in a large data collection exercise undertaken by GaWC researchers at Northumbria University and Loughborough University, UK and Ghent University, Belgium, in collaboration with the Chinese Academy of Social Sciences (CASS) in Beijing. Starting point for the identification of relevant TNMCs was the Forbes 2000 list of leading companies published in April 2011. All companies listed in the industry categories "Broadcasting \& Cable" (30) and "Printing \& Publishing" (12) were initially considered for inclusion in the analysis (Table 1). Additional information on the global presence of each firm was then collected from corporate websites. In this process, 18 of the original 42 Forbes 2000 media firms were excluded from further analysis because detailed data on office location were not available except for information on the headquarters (Table 1). Of these firms, 11 are predominantly broadcasting providers in national markets in North America (7), the UK (3) and Japan (1) and their exclusion is therefore of limited impact in the context of this study as the focus is on media firms linking cities across national boundaries. 7 of the 31 genuine TNMCs in the list (23 per cent) for which detailed locational data could not be traced represent a mix of firms with global or world-regional reach and home markets in North America (4) and Europe (3). The final list of TNMCs in the analysis comprises of 24 companies, of which 14 are in "Broadcasting \& Cable" and 10 in "Printing and Publishing". Although this does not represent the full population of media corporations listed in the Forbes 2000, the study includes 17 of the top 20 firms with significant transnational engagement. The findings are 
therefore robust in terms of the identified transnational links but potentially underplay the strength of some of the national linkages in the US, the UK and Japan.

For each of the 24 companies, information was gathered on the location and importance of headquarters and branch offices in 526 cities worldwide. These are the same cities as those included in the APS data collection to enable comparison of the findings (i.e. all cities with a population of over 2 million, all capital cities of countries with more than 1 million inhabitants, all cities with a headquarters of a major APS firm, and cities identified as important in previous analyses; see Taylor et al. 2011). Firm locations in the wider functional area of a city were allocated to the core city. The available information for each firm's office location was standardised to categorise its importance in a firm's organisational network. This 'media value' was coded from 0 (no office in the city) to 5 (headquarters), with a 'typical' office of a firm scoring 2 ( 1 for a minor office, 3 for a particularly large office, 4 for significant additional functions, e.g. a regional headquarters). The result is a matrix of 24 firms $\times 526$ cities with 12,624 values. This 2011 media value matrix was used for a two-fold analysis: first, media network connectivities were calculated for each city as indicated above, which measure their integration in transnational media networks. Second, a reduced matrix was analysed directly using principal components analysis to uncover common spatial strategies of global media firms. 


\section{Global Media Cities in Transnational Media Networks}

The emerging system of global media cities can be illustrated through an examination of the locational networks of major TNMCs. Table 2 displays a list of the top 25 most connected media cities, calculated through application of the interlocking network model to the data matrix. The resulting media network connectivities are presented as proportions of the highest city connectivity - in this instance New York. Table 2 also compares the media rank with the advanced producer services rank for these cities in 2010. London and New York dominate both the media and services rankings as the pre-eminent global cities dyad (NYLON), although their position is switched compared with the services rankings. New York is the most connected global media city, ahead of London. The US city houses by far the highest number of headquarters of leading media firms (6 out of the 24 firms included in the analysis and 10 out of the 42 media corporations included in Forbes), reflecting its role as a major "global creative hub" (Currid 2006). There is a substantive gap between the first two cities and Paris, ranked third, followed by 22 cities that score at least 40 per cent of New York's media network connectivity. In terms of world-regional distribution of leading media cities, all three 'globalisation arenas', North America, Europe and Pacific Asia, are equally represented in the top 10 (3 each) and the top 25 (North America and Europe 7 each, Pacific Asia 8). Other world regions are represented by one city only in the top 25: Buenos Aires in South America, Dubai in the Middle East and Mumbai in South Asia. The first African city to appear in the media connectivity ranking is Johannesburg at 31 with a media network connectivity of 36 per cent. 
Table 2: Media vs. advanced producer services (APS) rankings for the top 25 most connected media cities 2011

\begin{tabular}{|c|c|c|c|c|}
\hline $\begin{array}{l}\text { Media } \\
\text { rank }\end{array}$ & City & $\begin{array}{l}\text { Media network } \\
\text { connectivity }\end{array}$ & $\begin{array}{l}\text { APS } \\
\text { rank }^{\star \star}\end{array}$ & $\begin{array}{l}\text { Media vs. APS } \\
\text { rank }\end{array}$ \\
\hline 1 & New York & 100 & 2 & +1 \\
\hline 2 & London & 90 & 1 & -1 \\
\hline 3 & Paris & 64 & 4 & +1 \\
\hline 4 & Singapore & 53 & 5 & +1 \\
\hline 5 & Sydney & 52 & 10 & +5 \\
\hline 6 & Tokyo & 52 & 6 & +- \\
\hline 7 & Los Angeles & 52 & 17 & +10 \\
\hline 8 & Amsterdam & 49 & 21 & +13 \\
\hline 9 & Washington, DC & 49 & 28 & +19 \\
\hline 10 & Buenos Aires & 48 & 22 & +12 \\
\hline 11 & Chicago & 48 & 8 & -3 \\
\hline 12 & Madrid & 48 & 15 & +3 \\
\hline 13 & Mexico City & 46 & 20 & +7 \\
\hline 14 & San Francisco & 45 & 27 & +13 \\
\hline 15 & Shanghai & 45 & 7 & -8 \\
\hline 16 & Taipei & 45 & 43 & +27 \\
\hline 17 & Stockholm & 44 & 49 & +32 \\
\hline 18 & Warsaw & 43 & 37 & +19 \\
\hline 19 & Dubai & 42 & 9 & -10 \\
\hline 20 & Beijing & 42 & 12 & -8 \\
\hline 21 & Toronto & 42 & 13 & -8 \\
\hline 22 & Hong Kong & 42 & 3 & -19 \\
\hline 23 & Mumbai & 41 & 16 & -7 \\
\hline 24 & Seoul & 41 & 24 & +- \\
\hline 25 & Milan & 40 & 11 & -14 \\
\hline
\end{tabular}

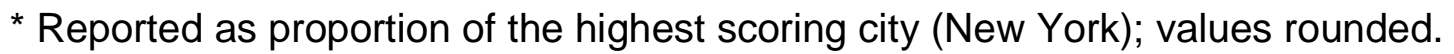

** The APS ranks for 2010 are based on network connectivities derived from an analysis of a 175 firms $\times 526$ cities matrix (75 financial services firms, 25 firms each in accountancy, advertising, law and management consultancy).

Source of APS rank: http://www.lboro.ac.uk/gawc/world2010t.html. 
Of particular interest to research on world city formation is the question to which degree the integration of leading cities into advanced producer services networks is mirrored in other industries and spheres of globalisation. The findings point to some overlap but also to distinctive differences. Only five of the top 25 media cities are not listed among the top 25 APS cities. The six highest ranked global service centres are also the best integrated global media cities, with the exception of Hong Kong, which loses considerably in rank reflecting its declining fortune as a Chinese 'media capital' since the late 1990s (Curtin 2010). There are ten cities in the top 25 that are positioned much higher as media cities than as APS cities. A significant number of these are capital cities with high concentrations of media activity (Washington DC, Buenos Aires, Mexico City, Taipei, Stockholm and Warsaw), plus cities with a substantive presence of cultural industries (Sydney, Los Angeles, Amsterdam, San Francisco). Cities that rank substantially lower on media than services are predominantly located in emerging markets, e.g. in BRICs countries (Shanghai, Beijing, Hong Kong, Mumbai, Sao Paulo, Moscow), the United Arab Emirates (Dubai) and Malaysia (Kuala Lumpur), as well as in leading economic non-capital cities in the West (Toronto, Milan, Frankfurt), plus, less obvious, Europe's political capital, Brussels.

In contrast to Krätke and Taylor's (2004) study of global media cities in the early 2000s, which included a number of smaller European-based companies in the data, the finding of a 'privileged Europe' is not mirrored in this analysis of the leading TNMCs at the beginning of the next decade, which shows a more balanced geography of media cities across Europe, North America and Pacific Asia (Figure 
1). The spatial configuration of the global media networks anchored in these cities can be further explored through a principal components analysis.

\section{The Spatial Configuration of Global Media Networks}

The 24 firms $\times 526$ cities media value matrix described above contains information about the presence of TNMCs in each of the 526 cities (rows) and about the global locational strategies of each of the 24 firms (columns). In addition to calculating network connectivities for each city, a number of techniques can be employed to uncover structural patterns in the data. Principal components analysis (PCA) in particular has provided a useful tool in previous studies of the world city network, both on a global scale (e.g. Taylor \& Walker 2001; Krätke \& Taylor 2004) and in regional analyses (e.g. Taylor \& Hoyler 2000; Taylor et al. 2000). This method in data reduction converts large data matrices like the media value matrix into smaller matrices by combining similar variables (here the 24 location strategies of individual firms) into components (Griffith \& Amrhein 1997). These highlight common patterns (similar strategies) in the way in which global media firms use particular cities. The first component accounts for the largest share of the overall variance, the second for the largest residual variance, and so on through components. This allows the variance of a large data matrix to be accounted for by a relatively small number of principal components. Interpretability can be enhanced and distinctive clusters of variables uncovered by rotating the results (Griffith \& Amrhein 1997) - in effect a second rotation clustering variables into groups (Jackson 1991). To ease interpretation, varimax rotation has been undertaken on the data to maximise all variances accounted for in the data. 
One limitation of principal components analysis is that it is sensitive to sparseness in the data, where the matrix contains a large number of zero values. To counter this difficulty, the matrix of 24 firms $\times 526$ cities was reduced to 24 firms x 263 cities, by removing all cities without presence of global media firms. Following Taylor et al. (2002), an exploratory strategy was employed in analysing this matrix, and a number of different principal component analyses were performed on the data. The importance of each individual analysis to understanding the data was considered. In this particular study, the data matrix was reduced into a single solution containing six components. This solution accounts for 58.9 per cent of the original variation of the data in the matrix. In order to interpret the patterns obtained from the principal components analysis, it is necessary to identify which of the global media firms in the original matrix are associated with the various components. Table 3 shows the highest loadings for the media firms on each of the six components in the solution. Firms with larger loadings (higher correlations) are those with a more important role in producing the patterns reported in the analysis. Alongside the component loadings for the media firms, the analysis also provides component scores for the cities in the matrix. It is these scores that give insight into the spatial configuration of global media networks. The higher the score for a given city, the more significant its role in articulating media services across the world. 
Table 3: Highest loadings for media firms (greater than 0.4) on six components

\begin{tabular}{|c|c|c|c|c|c|}
\hline 1 & 2 & 3 & 4 & 5 & 6 \\
\hline $\begin{array}{c}\text { Naspers } \\
\text { (Cape Town) } \\
0.73\end{array}$ & $\begin{array}{c}\text { Directv } \\
\text { (Los Angeles) } \\
0.821\end{array}$ & $\begin{array}{c}\text { Eutelsat } \\
\text { Comms } \\
\text { (Paris) } \\
0.7\end{array}$ & $\begin{array}{c}\text { Nielsen } \\
\text { Holdings } \\
\text { (New York) } \\
0.77\end{array}$ & $\begin{array}{c}\text { Dai Nippon } \\
\text { Printing } \\
\text { (Tokyo) } \\
0.90\end{array}$ & $\begin{array}{c}\text { Modern } \\
\text { Times Group } \\
\text { (Stockholm) } \\
0.76\end{array}$ \\
\hline $\begin{array}{c}\text { Reed Elsevier } \\
\text { (London) } \\
0.72\end{array}$ & $\begin{array}{c}\text { Scripps } \\
\text { Networks } \\
\text { (Knoxville) } \\
0.80\end{array}$ & $\begin{array}{c}\text { RTL Group } \\
\text { (Luxembourg) } \\
0.68\end{array}$ & $\begin{array}{c}\text { Pearson } \\
\text { (London) } \\
0.54\end{array}$ & $\begin{array}{c}\text { Toppan } \\
\text { Printing } \\
\text { (Tokyo) } \\
0.87\end{array}$ & $\begin{array}{c}\text { Discovery } \\
\text { Comms } \\
\text { (Washington) } \\
0.55\end{array}$ \\
\hline $\begin{array}{c}\text { McGraw-Hill } \\
\text { (New York) } \\
0.65\end{array}$ & $\begin{array}{c}\text { Viacom } \\
\text { (New York) } \\
0.73\end{array}$ & $\begin{array}{c}\text { Axel Springer } \\
\text { (Berlin) } \\
0.56\end{array}$ & $\begin{array}{c}\text { RR Donnelley \& } \\
\text { Sons } \\
\text { (Chicago) } \\
0.49\end{array}$ & & \\
\hline
\end{tabular}

\begin{tabular}{|c|c|c|c|}
\hline $\begin{array}{c}\text { Discovery } \\
\text { Comms } \\
\text { (Washington) }\end{array}$ & $\begin{array}{c}\text { RR Donnelley \& } \\
\text { Sons } \\
\text { (Chicago) }\end{array}$ & $\begin{array}{c}\text { Vivendi } \\
\text { (Paris) } \\
0.45\end{array}$ & $\begin{array}{l}\text { CC Media } \\
\text { Holdings } \\
\text { (San Antonio) }\end{array}$ \\
\hline 0.55 & 0.48 & & 0.46 \\
\hline $\begin{array}{l}\text { Time Warner } \\
\text { (New York) }\end{array}$ & $\begin{array}{c}\text { Comcast } \\
\text { (Philadelphia) }\end{array}$ & $\begin{array}{l}\text { CC Media } \\
\text { Holdings }\end{array}$ & $\begin{array}{l}\text { Thomson } \\
\text { Reuters }\end{array}$ \\
\hline 0.53 & 0.45 & $\begin{array}{c}\text { (San Antonio) } \\
0.41\end{array}$ & $\begin{array}{c}\text { (New York) } \\
0.44\end{array}$ \\
\hline
\end{tabular}

\begin{tabular}{cc}
\hline News Corp & SES \\
(New York) & (Luxembourg) \\
0.49 & 0.40 \\
& \\
\hline Pearson & \\
(London) & \\
0.45 & \\
& \\
Comcast & \\
(Philadelphia) & \\
0.44 & \\
Thomson \\
Reuters \\
(New York)
\end{tabular}


0.44

SES

(Luxembourg)

0.42

In the following sections, the results from the six component solution are used to describe six global media fields that represent distinctive locational firm strategies. Cities are allocated to a series of categories: Super-articulator cities represent the small number of cities that achieve very high component scores above 7.0. Articulator cities represent cities with high component scores between 4.0 and 7.0. Primary field cities are cities scoring between 2.0 and 4.0 , while subprimary field cities score between 1.0 and 2.0. Cities scoring between 0.5 and 1.0 are allocated to the category of secondary field cities. These allocations are presented on a cartogram, showing cities in their approximate location, for each of the six media fields. The components are labeled by dominant geographical patterns that emerge from the component scores. The findings identify two global strategies and four regional/national strategies. Two of the latter are European; one is focused on the US, and one on Japan. These strategies will be discussed in turn, following the rank order in terms of incorporated data variance.

\section{Global media strategy I}

This is the first of two global media strategies identified in the analysis, accounting for 14.9 per cent of the total variance. This media field contains ten major media firms with loadings above 0.4 (Table 3), including four of the five top publishing corporations, with headquarters in the US (New York) or the UK 
(London), plus four US-headquartered and one European and one South African broadcasting firms. The strategy of these firms (Figure 2) is global in nature, but with particularly strong coverage of North America. This demonstrates that while the networks of US TNMCs may have global reach, US media corporations remain strongly territorially anchored in US cities, reflecting both the size of media markets within the US, and the importance of these home base markets for US TNMCs (Chan 2005). The field is articulated through a number of primary field cities in the three globalisation arenas plus Sao Paulo in South America and Mumbai and New Delhi in South Asia. Beijing appears as the highest scoring city but other major Chinese cities score relatively low. All major world regions are represented in this locational strategy with at least one city.

\section{US media strategy}

Component two (11.9\% of total variance) represents an almost exclusive US strategy (Figure 3). This media field contains five major media firms with loadings above 0.4 , all of which are headquartered in the US (Table 3). These are media corporations predominantly operating in the cable and satellite TV market, plus one printing firm. Los Angeles is the super-articulator of this field, followed by New York, Chicago and Atlanta, covering West, East, Midwest and South. A further eight US cities appear in this component. These findings correspond to those of Krätke and Taylor (2004), who identify a media field articulated through New York and Los Angeles and with a strong US orientation. However, unlike their field which contains a number of cities in the Pacific Rim, the strategy identified here has an almost exclusively US focus, with only two cities outside the US featuring in the strategy with a minor role. These results underline the importance of the US home 
base markets for US cable and satellite TV corporations, which effectively ensures that they do not "stray too far from their home culture" (Chan 2005, p. 26).

\section{European media strategy}

Component three ( $9 \%$ of the total variance) is very European in its focus. The media field contains six major media firms with loadings above 0.4 (Table 3), five of which are headquartered in continental Europe (two in Paris and in Luxembourg, one in Berlin). Paris is the superarticulator city in this strategy, followed by Berlin and ten other European cities (Figure 4). Krätke and Taylor (2004) also identify a media strategy articulated through Paris that has a European bias; however, while their field has a good representation in several world regions, the strategy identified here has an almost exclusively European focus. Cities outside of Europe all fall into the lowest two categories. The geography of their distribution is intriguing: there is no presence of any Asian or Middle Eastern cities in this strategy, and other world regions are represented by just one or two cities, with the exception of North America, which shows an emphasis on the South West (the sixth firm, CC Media Holdings, is headquartered in San Antonio). Furthermore, Krätke and Taylor (2004) identify three more Western European components articulated through, London, Rome, and Munich and Berlin, and thus argue that "Europe is the world region ... in which these media firms and their international location networks are intensively anchored" (2004: 465-466). However, while Europe remains an important location in the organisational networks of global media firms in 2011, the two European strategies identified in this analysis, with limited representation in other world regions, point to more restricted locational moves beyond Europe of leading continental European media firms. 


\section{Global media strategy II}

Component four $(8.5 \%$ of the total variance) contains five firms with loadings above 0.4 (Table 3). All but one of these firms have headquarters in the US and four of the five are from the printing and publishing industry. New York and Chicago are key cities in this strategy but in contrast to the very US-centred strategy apparent in component two, this is a US-led global strategy (Figure 5). Cities of both the global North and South are well represented in this strategy, which reaches out more widely than global strategy I and includes fewer cities in the US itself. These results are reflective of a smaller number of US printing and publishing corporations who, compared to the strategy of the US cable and satellite TV corporations, have adopted a far more global outlook and are less reliant on the domestic US media market.

\section{Japanese media strategy}

Component five ( $8.1 \%$ of the total variance) is the first of two strategies that contain just two global media firms with loadings above 0.4. Both firms are Japanese printing corporations headquartered in Tokyo with a strategy that focuses on the home region (Figure 6). Tokyo is the sole articulator city, with a strong presence of other Japanese and Pacific Asian cities. However, Europe and North America also feature strategically, with the major media hubs London, New York and Paris as well as a number of other cities represented. A remarkable feature of the strategy is the complete absence of South American or African cities and the exclusive focus on the major globalisation arenas. Central to the strategy identified here are rapidly growing Japanese media firms, with Japan home to three of the world's top 42 media corporations as listed in the Forbes 2000 . The 
expanding East Asian media markets provide these Japanese corporations with their largest export market (Iwabuchi 2007). This is reflected in the importance of Pacific Rim cities in the media field: Shanghai, Taipei and Seoul appear prominently, as do Singapore, Jakarta and Sydney. All of this has been driven by the "activation of regional media flows" (Iwabuchi 2007, p. 70) as media products created in these cities find more acceptance across the region and, particularly in the case of Japanese media, are also "making inroads into the global markets in some areas" (Chan 2005, p. 26). This is indicated in the inclusion of major media hubs in Europe and North America in the strategy.

\section{Northern European media strategy}

Component six (6.4\% of the total variance) also includes only two global media firms with a loading above 0.4, one based in Stockholm and one in Washington DC. This represents an alternative European strategy with a focus on Northern Europe but significant presence in other European cities (Figure 7). Other world regions are included in the strategy, notably the US, plus key strategic locations elsewhere. These findings again correspond closely with those of Krätke and Taylor (2004), who identify a media field articulated through Stockholm, Copenhagen, and Oslo, although in the strategy identified here Stockholm acts as the sole articulating city, while both Copenhagen and Oslo are primary field cities, along with Helsinki. The more significant difference in the strategy is the importance of Eastern European capital cities: Prague, Riga, Moscow, Kiev, Budapest and Sofia are all primary field cities in this strategy, which points to continued expansion of international media activities in post-socialist Central and Eastern European economies, driven by the potential profitability of this market, a 
conducive regulatory environment and relative lack of domestic competition (Downey 2012).

\section{Discussion and Conclusions}

The analysis of global media city connectivities and media fields reveals a number of interesting characteristics regarding the urban networks of TNMCs. The main finding is the continuing strong regionality of global corporate media strategies. The results of the principal components analysis show how the world's largest media corporations remain firmly anchored in the three major home markets of North America, Europe and Japan. The core tendencies of the global market - seeking out the most profitable areas to sell media products and advertising - continue to produce a highly uneven worldwide media system (Herman \& McChesney 1997). Thus the geography of the media strategies outlined above can be seen to centre on the wealthiest regions of the world. For example, Chan-Olmsted and Chang (2003) found US media corporations to be less geographically diversified than non-US corporations, due to the importance of their home market. The leading US TNMCs Disney, Time Warner and Viacom for instance derive only $20-25$ per cent of their total operating revenues from outside North America (Flew 2007). The results presented here demonstrate in particular, the high importance of the US home base markets for US headquartered cable and satellite TV corporations, which predominantly create and distribute media products that meet the demands and tastes of US TV consumers. Similarly, leading media corporations in Japan focus strongly on their national home market, 
while media giants based in continental Europe follow a more explicit regional expansion strategy.

This is not to say however that the major TNMCs are not globally networked. Indeed, the analysis has identified two global media strategies, the results of which demonstrate that the networks of TNMCs reach out to other world regions, accessing these regions through strategically positioned media cities. A particularly important region in this respect is Pacific Asia. The non-emergence of a Pacific Asian component from the principal components analysis indicates that the region is not a home region for global media corporations (excluding the presence of Japan as a national home region). This corresponds with Flew's (2010) contention that the absence of regulatory harmonisation in media policies in East Asia limits the ability of aspiring media capitals in the region to expand beyond their national markets. However, the high levels of connectivity of key Pacific Asian cities, in particular Singapore, Sydney, Tokyo, Shanghai, Taipei, Beijing, Hong Kong and Seoul (see Table 2), indicate that Pacific Asia is a region that is very strongly integrated into global media networks. Other world regions are also shown to be connected into wider media networks through strategically linked media cities, for example Latin America through Buenos Aires and Mexico City.

The regionality that emerges from the results supports Castells' (2009) assertion that TNMCs are not in themselves global corporations. Rather, Castells (2009, p. 72) argues that it is "networks of interlocked multimedia businesses organized around strategic partnerships", as well as cross-investments, personnel, production and distribution, that have global reach. US and European TNMCs, for 
example, have managed to gain substantial holdings in the Pacific Asian region through a web of corporate alliances with domestic and regional businesses and other TNMCs, in an attempt to share in the profitability of Asia's large potential media audiences (Sussman \& Lent 1999). The US headquartered News Corporation, for example, which receives 44 per cent of its revenues from outside North America, has a particularly strong presence in Asia not only through its STAR cable network programming business and Fox International Channels, but also through large equity stakes in a number of other networks based in China, India and Singapore (News Corporation 2011; see also Arsenault \& Castells 2008b). It should not be assumed, however, that the expansion of TNMCs is undermining local media industries and cultural production. Rather, as TNMCs attempt to expand their markets they are forced to compete with well-established and often highly competitive local media organisations (Flew 2007).

This paper has provided a measurement of the level of integration of cities into the world city network based on the global media, as an alternative dimension to more common measurements that consider the servicing of global capital. It has demonstrated the central role performed by key 'global media cities' within transnational media networks. Media cities emerge in this extensive analysis as nodes in the organisational networks of major firms, but besides the offices and subsidiaries of large TNMCs they also house many smaller media organisations and associated services, creating distinctive media clusters connected internally and externally through a multitude of networks. These multiple networks link media cities to other cities across the globe in a complex pattern of connections and flows, only part of which could be captured in the analysis above. The study 
presented here has focused on the "backbone" (Castells 2009, p. 73) of the global media network as revealed in the locational strategies of leading TNMCs. However, global media cities are much more than nodes in intra-firm flows. To fully explore the changing geographies of global media cities requires both in-depth studies of individual cities as well as historically informed relational accounts of the shared characteristics that explain the rise of particular cities as 'media capitals', for example in terms of their specific institutional structures, creative capacities and regulatory policies (Curtin 2010, p. 265).

\section{Acknowledgement}

The authors are grateful to Ben Derudder and Stephanie Vervaet (Ghent University) for their support with the 2011 TNMC data collection.

\section{References}

Alderson, A. S. \& J. Beckfield (2004), Power and Position in the World City System. American Journal of Sociology 109, pp. 811-851.

Alderson, A. S. \& J. BeCKFIelD (2012), Corporate Networks of World Cities. In: B.

DeRUdDER, M. HOYLER, P. J. TAYLOR \& F. WitLoX, eds., International Handbook of Globalization and World Cities, pp. 126-134. Cheltenham: Edward Elgar. 
Arsenault, A. H. \& M. Castells (2008a), The Structure and Dynamics of Global Multi-media Business Networks. International Journal of Communication 2, pp. 707-748.

Arsenault, A. \& M. Castells (2008b), Switching Power: Rupert Murdoch and the Global Business of Media Politics. International Sociology 23, pp. 488-513.

Castells, M. (2009), Communication Power. Oxford: Oxford University Press.

CHALABY, J. K. (2005), From Internationalization to Transnationalization. Global Media and Communication 1, pp. 28-33.

CHAN, J. (2005), Global Media and the Dialectics of the Global. Global Media and Communication 1, pp. 24-28.

Chan-Olmsted, S. M. \& B. Chang (2003), Diversification Strategy of Global Media Conglomerates: Examining its Patterns and Determinants. Journal of Media Economics 16, pp. 213-233.

CuRRID, E. (2006), New York as a Global Creative Hub: A Competitive Analysis of Four Theories on World Cities. Economic Development Quarterly 20, pp. 330-350.

Curtin, M. (2003), Media Capital: Towards the Study of Spatial Flows. International Journal of Cultural Studies 6, pp. 202-228. 
CuRTIN, M. (2009), Thinking Globally: From Media Imperialism to Media Capital. In:

J. Holt \& A. Perren, eds., Media Industries: History, Theory, and Method, pp. 108-119. Chichester: Wiley-Blackwell.

CuRTin, M. (2010), Comparing Media Capitals: Hong Kong and Mumbai. Global Media and Communication 6, pp. 263-270.

DowneY, J. (2012), Transnational Capital, Media Differentiation, and Institutional Isomorphism in Central and Eastern European Media Systems. In: J. DOWNEY \& S. MıHELJ, eds., Central and Eastern European Media in Comparative Perspective: Politics, Economy and Culture, pp. 113-136. Farnham: Ashgate.

FLEW, T. (2005), New Media: An Introduction. Oxford: Oxford University Press.

FLEW, T. (2007), Understanding Global Media. Basingstoke: Palgrave MacMillan.

FLEW, T. (2010), Cultural Economic Geography and Global Media Studies: The Rise of Asian Media Capitals? Journal of the Oriental Society of Australia 42, pp. 35-49.

Gershon, R. A. (1997), The Transnational Media Corporation: Global Messages and Free Market Competition. Mahwah, NJ: Lawrence Erlbaum Associates. 
GeRSHON, R. A. (2000), The Transnational Media Corporation: Environmental Scanning and Strategy Formulation. The Journal of Media Economics 13, pp. 81101.

GodfreY, B. J. \& Y. ZHOU (1999), Ranking World Cities: Multinational Corporations and the Global Urban Hierarchy. Urban Geography 20, pp. 268-281.

Griffith, D. A. \& C. G. AmRheIN (1997), Multivariate Statistical Analysis for Geographers. London: Prentice Hall.

Held, D., A. McGrew, D. Goldblatt \& J. Perraton (1999), Global Transformations: Politics, Economics and Culture. Stanford: Stanford University Press.

Herman, E. S. \& R. W. McChesney (1997), The Global Media: The New Missionaries of Global Capitalism. London: Cassell.

Hoyler, M., R. C. Kloosterman \& M. Sokol (2008), Polycentric Puzzles Emerging Mega-City Regions Seen through the Lens of Advanced Producer Services. Regional Studies 42, pp. 1055-1064.

IWABUCHI, K. (2007), Contra-Flows or the Cultural Logic of Uneven Globalization? Japanese Media in the Global Agora. In: D. K. Thussu, ed., Media on the Move: Global Flow and Contra-Flow, pp. 61-75. Abingdon: Routledge. 
JaCkson, J. E. (1991), A User's Guide to Principal Components. New York: Wiley.

KRÄTKE, S. (2002), Medienstadt: Urbane Cluster und globale Zentren der Kulturproduktion. Opladen: Leske + Budrich.

KRÄTKE, S. (2003), Global Media Cities in a Worldwide Urban Network. European Planning Studies 11, pp. 605-628.

KRÄTKE, S. (2006), 'Global Media Cities': Major Nodes of Globalizing Culture and Media Industries. In: N. BRENNER \& R. KEIL, eds., The Global Cities Reader, pp. 325-331. Abingdon: Routledge.

KRÄTKE, S. (2011), How Manufacturing Industries Connect Cities across the World: Extending Research on 'Multiple Globalizations'. GaWC Research Bulletin 391. Available at <http://www.lboro.ac.uk/gawc/rb/rb391.html>.

KrätKe, S. \& P. J. TAYLOR (2004), A World Geography of Global Media Cities. European Planning Studies 12, pp. 459-477.

McChesneY, R. W. (1998), Media Convergence and Globalisation. In: D. K. THussu, ed., Electronic Empires: Global Media and Resistance, pp. 27-46. London: Arnold.

Morley, D. \& K. Robins (1995), Spaces of Identity: Global Media, Electronic Landscapes and Cultural Boundaries. London: Routledge. 
News Corporation (2011), Annual Report 2011. New York: News Corporation. Available at <http://www.newscorp.com/investor/annual_reports.html> .

Sassen, S. (1991), The Global City: New York, London, Tokyo. Princeton, NJ: Princeton University Press.

ScotT, A. (2000), The Cultural Economy of Cities. London: Sage.

Sussman, G. \& J. A. LeNT (1999), Who Speaks for Asia: Media and Information Control in the Global Economy. The Journal of Media Economics 12, pp. 133-147.

TAYLOR, P. J. (2001), Specification of the World City Network. Geographical Analysis 33, pp. 181-194.

TAYLOR, P. J. (2004), World City Network: A Global Urban Analysis. London: Routledge.

TAYLOR, P. J. (2005), Leading World Cities: Empirical Evaluations of Urban Nodes in Multiple Networks. Urban Studies 42, pp. 1593-1608.

TAyloR, P. J., G. Catalano \& D. R. F. WalkeR (2002), Exploratory Analysis of the World City Network. Urban Studies 39, pp. 2377-2394.

TAyloR, P. J. \& G. Csomós (2011), Cities as Control and Command Centres: Analysis and Interpretation. Cities DOI:10.1016/j.cities.2011.09.005. 
Taylor, P. J., M. A. Doel, M. Hoyler, D. R. F. Walker \& J. V. Beaverstock (2000), World Cities in the Pacific Rim: A New Global Test of Regional Coherence. Singapore Journal of Tropical Geography 21, pp. 233-245.

TAYLOR, P. J. \& M. HOYLER (2000), The Spatial Order of European Cities under Conditions of Contemporary Globalisation. Tijdschrift voor Economische en Sociale Geografie 91, pp. 176-189.

TAYLOR, P. J. \& D. R. F. WALKER (2001), World Cities: A First Multivariate Analysis of their Service Complexes. Urban Studies 38, pp. 23-47.

TAylor, P. J., P. Ni, B. Derudder, M. Hoyler, J. Huang \& F. Witlox, eds., (2011), Global Urban Analysis: A Survey of Cities in Globalization. London: Earthscan.

WALL, R. S. \& G. A. VAN DER KNAAP (2011), Sectoral Differentiation and Network Structure Within Contemporary Worldwide Corporate Networks. Economic Geography 87, pp. 267-308.

WARF, B. (2007), Oligopolization of Global Media and Telecommunications and its Implications for Democracy. Ethics, Place and Environment 10, pp. 89-105. 
Figure 1: The top 50 most connected media cities in 2011

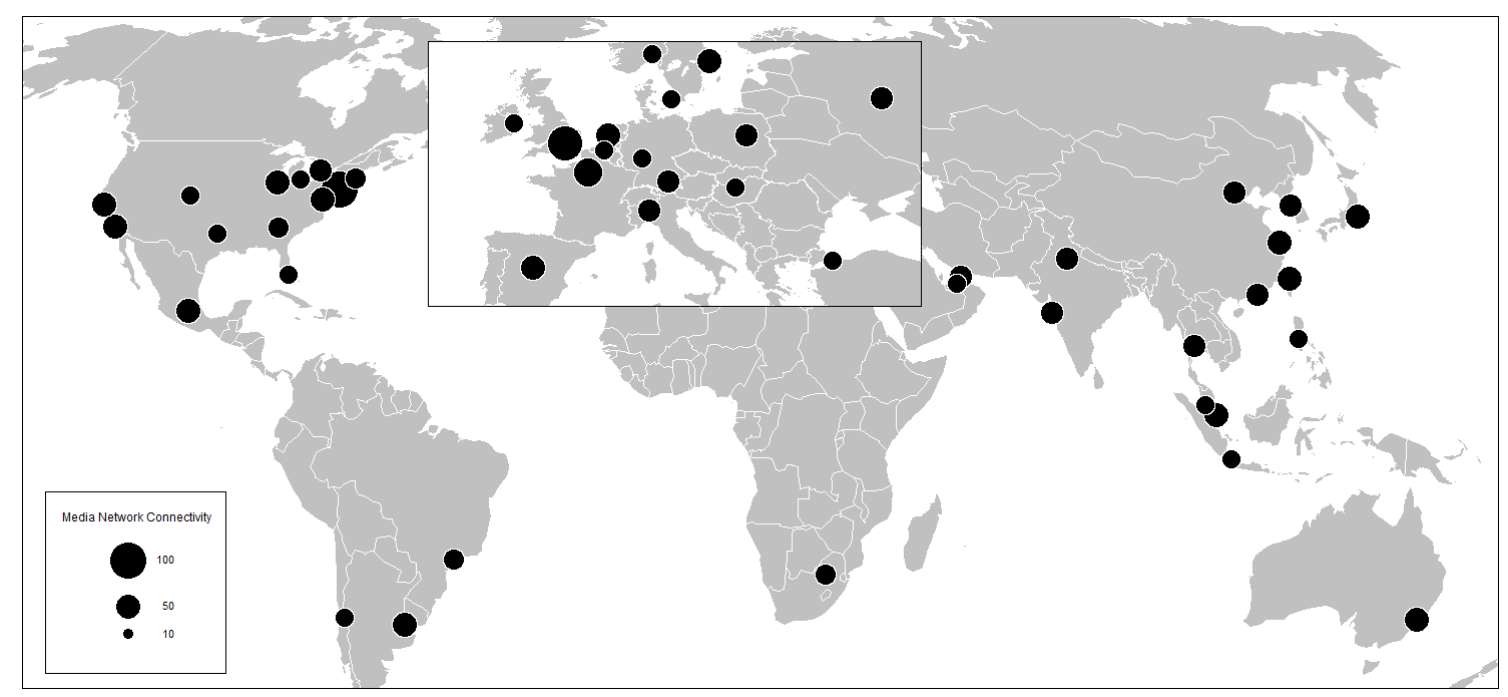


Figure 2: Global media strategy I
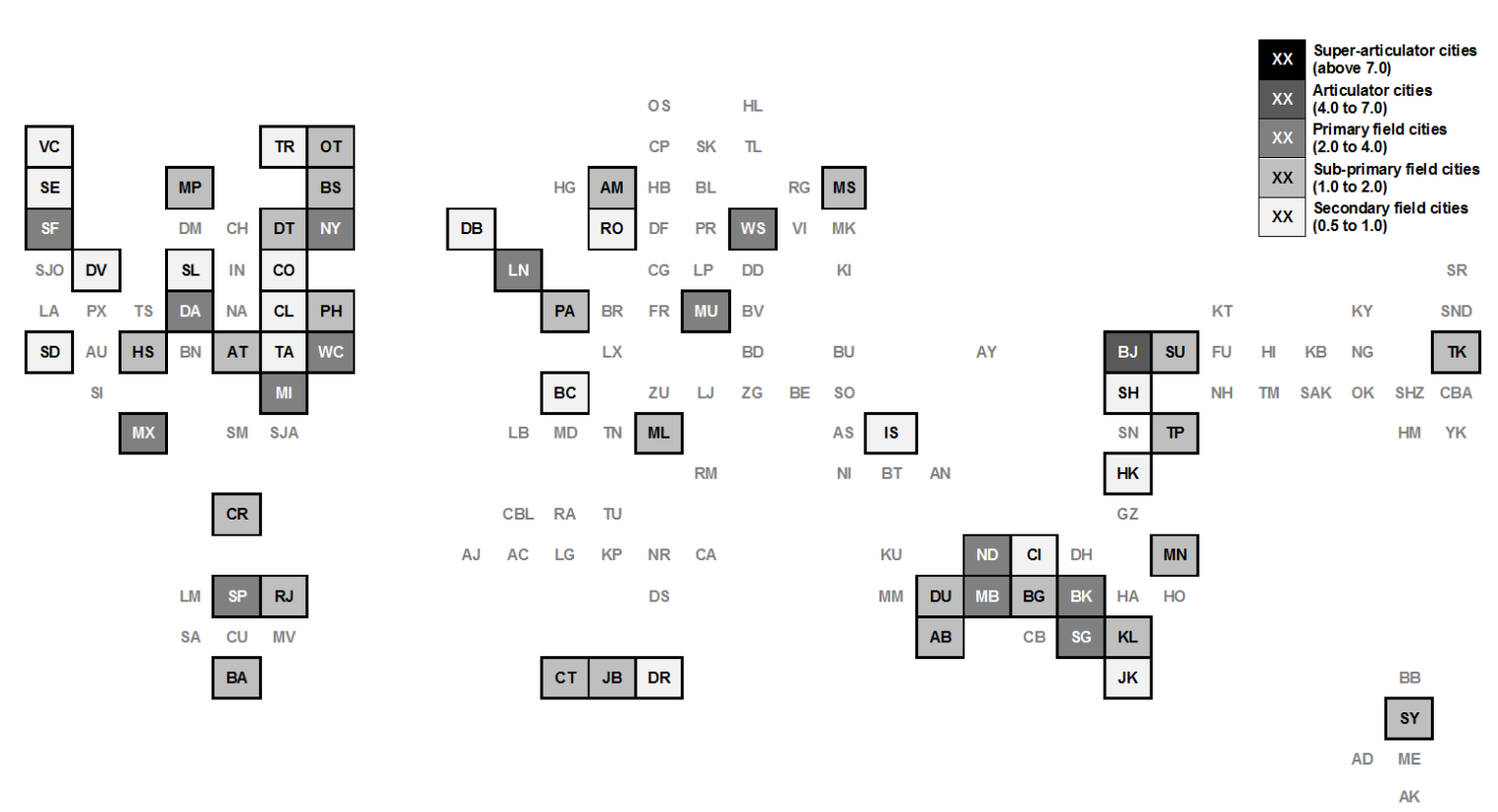

Note: The cartogram places cities in their approximate relative geographical positions. The city roster of 150 cities shows all cities with a score above 0.5 in one of the six identified components. Cities highlighted are those achieving such a score for a particular component.

Key: AB Abu Dhabi; AC Accra; AD Adelaide; AJ Abidjan; AK Auckland; AM Amsterdam; AN Amman; AS Athens; AT Atlanta; AU Austin; AY Almaty; BA Buenos Aires; BB Brisbane; BC Barcelona; BD Budapest; BE Belgrade; BG Bangalore; BJ Beijing; BK Bangkok; BL Berlin; BR Brussels; BS Boston; BN Birmingham (US); BT Beirut; BU Bucharest; BV Bratislava; CA Cairo; CB Colombo; CBA Chiba; CBL Casablanca; CG Cologne; CH Chicago; Cl Chennai; CL Charlotte; CO Columbus; CP Copenhagen; CR Caracas; CT Cape Town; CU Curitiba; DA Dallas; DB Dublin; DD Dresden; DF Düsseldorf; DH Dhaka; DM Des 
Moines; DR Durban; DS Dar Es Salaam; DT Detroit; DU Dubai; DV Denver; FR Frankfurt; FU Fukuoka; GZ Guangzhou; HA Hanoi; HB Hamburg; HG The Hague; HI Hiroshima; HK Hong Kong; HL Helsinki; HM Hamamatsu; HO Ho Chi Minh City; HS Houston; IN Indianapolis; IS Istanbul; JB Johannesburg; JK Jakarta; KB Kobe; KI Kiev; KL Kuala Lumpur; KP Kampala; KT Kitakyushu; KU Kuwait City; KY Kyoto; LA Los Angeles; LB Lisbon; LG Lagos; LJ Ljubljana; LM Lima; LN London; LP Leipzig; LX Luxembourg City; MB Mumbai; MD Madrid; ME Melbourne; MI Miami; MK Minsk; ML Milan; MM Manama; MN Manila; MP Minneapolis; MS Moscow; MU Munich; MV Montevideo; MX Mexico City; NA Nashville; ND New Delhi; NG Nagoya; NH Naha; NI Nicosia; NR Nairobi; NY New York; OK Osaka; OS Oslo; OT Ottawa; PA Paris; PH Philadelphia; PR Prague; PX Phoenix; RA Rabat; RG Riga; RJ Rio de Janeiro; RM Rome; RO Rotterdam; SA Santiago; SAK Sakai; SD San Diego; SE Seattle; SF San Francisco; SG Singapore; SH Shanghai; SHZ Shizuoka; SI San Antonio; SJA San Juan; SJO San Jose; SK Stockholm; SL St Louis; SM Santo Domingo; SN Shenzhen; SND Sendai; SO Sofia; SP Sao Paulo; SR Sapporo; SU Seoul; SY Sydney; TA Tampa; TK Tokyo; TL Tallinn; TM Takamatsu; TN Turin; TP Taipei; TR Toronto; TS Tulsa; TU Tunis; VC Vancouver; VI Vilnius; WC Washington DC; WS Warsaw; YK Yokohama; ZG Zagreb; ZU Zurich 
Figure 3: US media strategy (for key, see Figure 2)

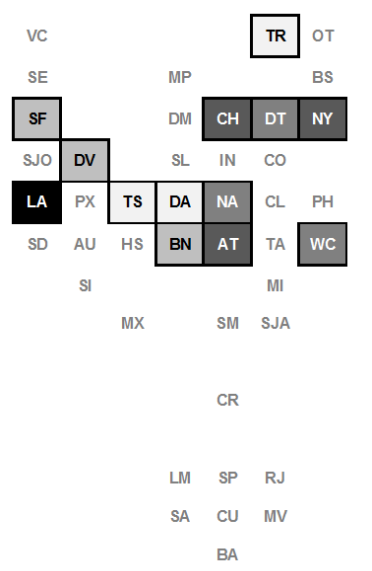

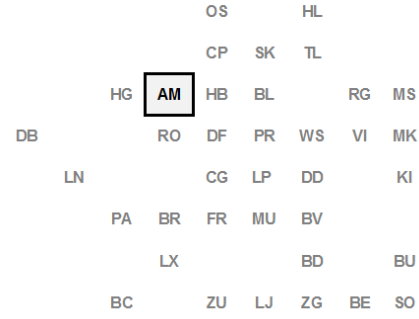

LB MD TN ML

CBL RA TU

AJ AC LG KP NR CA

DS

CT JB DR

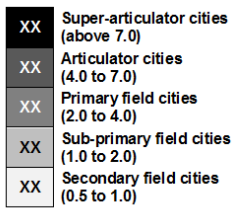

KT KY SND

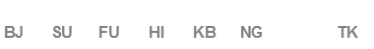

NH TM SAK OK SHZ CBA

SN TP HM YK

HK

GZ

KU ND $\quad \mathrm{Cl} \quad \mathrm{DH} \quad \mathrm{MN}$

MM DU MB BG BK НA НО

AB CB SG KL 
Figure 4: European media strategy (for key, see Figure 2)

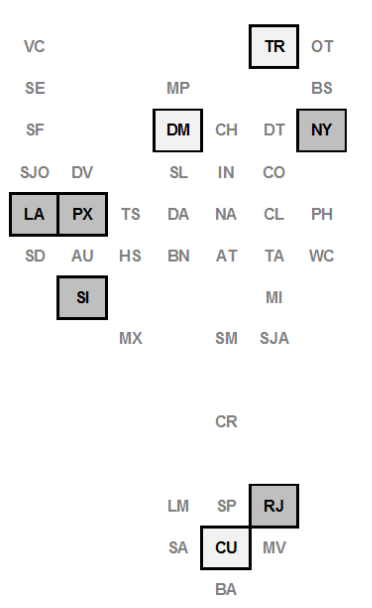

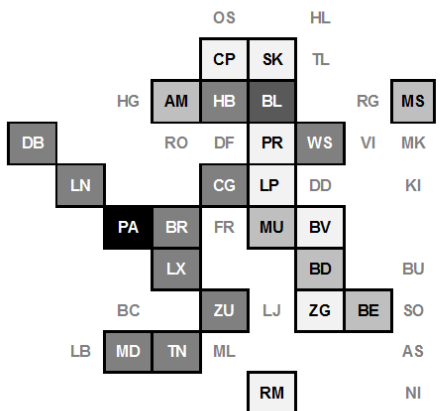

$\mathrm{CBL}$ RA TU

AJ AC LG KP NR CA

DS

CT JB DR

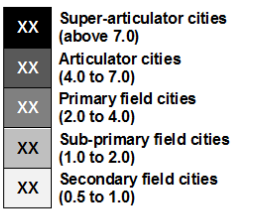

\begin{tabular}{l|l}
$\mathrm{XX}$ & $\begin{array}{l}\text { Sub-primary field cities } \\
(1.0 \text { to } 2.0)\end{array}$ \\
$\mathrm{xX}$ & $\begin{array}{l}\text { Secondary field cities } \\
(0.5 \text { to } 1.0)\end{array}$
\end{tabular}
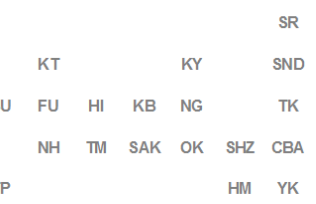

SN TP

HM YK

${ }_{A D}{ }_{M B}^{B B}$ 
Figure 5: Global media strategy II (for key, see Figure 2)

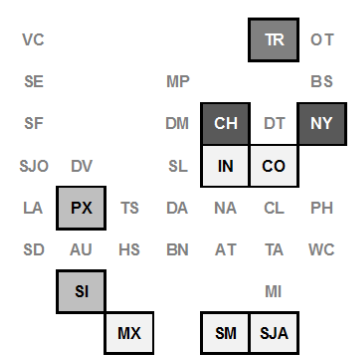

$\mathrm{CR}$

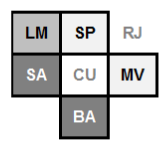

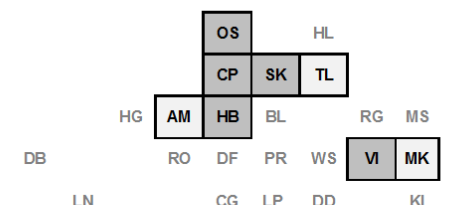

$$
\begin{aligned}
& \begin{array}{|l|l|l|l|l|l|l|}
\multicolumn{1}{c}{\text { LN }} & \multicolumn{1}{l}{\text { CG }} & \text { LP } & \text { DD } & \text { KI } \\
\hline \text { PA } & \text { BR } & \text { FR } & \text { MU } & \text { BV } \\
\hline
\end{array} \\
& \begin{array}{|l|l|l|l|}
\hline \text { PA } & \text { BR } & \text { FR } \\
\hline \multicolumn{3}{|c|}{M U} & \text { BV } \\
& \text { LX } & \text { BD } \\
\hline
\end{array}
\end{aligned}
$$

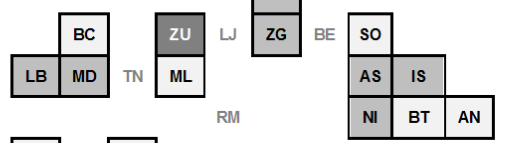

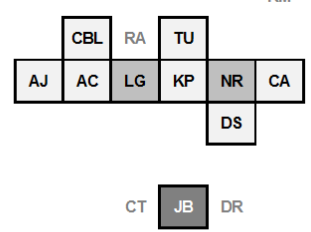

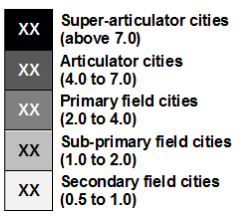

Secondary field cities
$(0.5$ to 1.0$)$

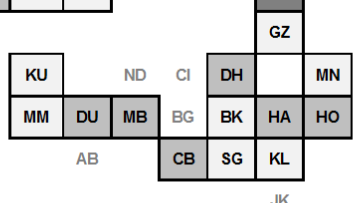


Figure 6: Japanese media strategy (for key, see Figure 2)
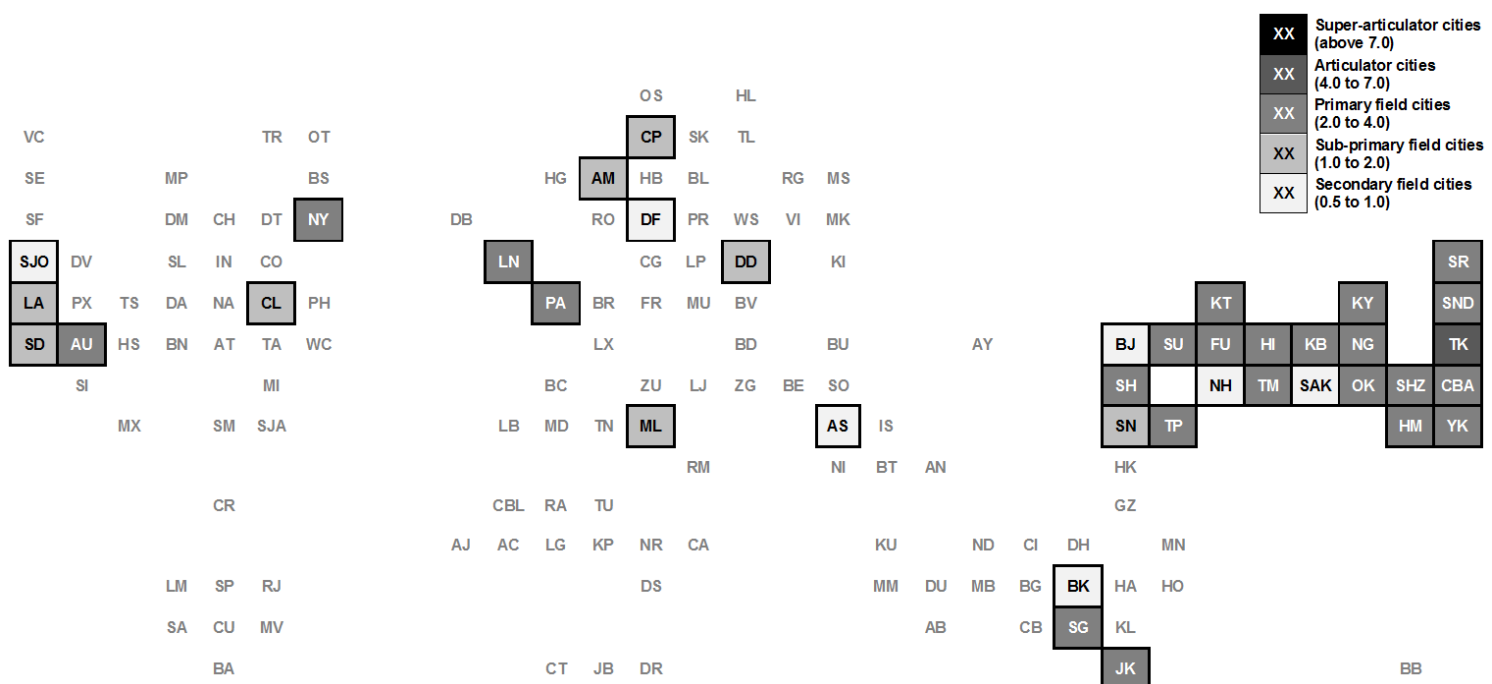

CBL RA TU

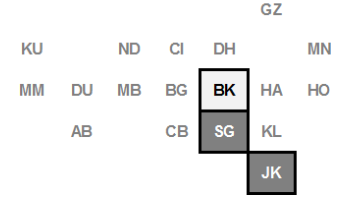

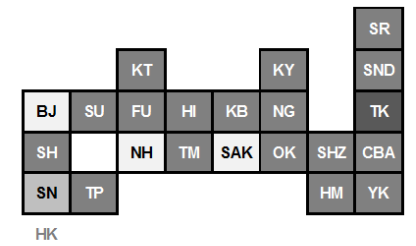

AJ AC LG KP NR CA

CT JB DR

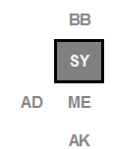


Figure 7: Northern European media strategy (for key, see Figure 2)

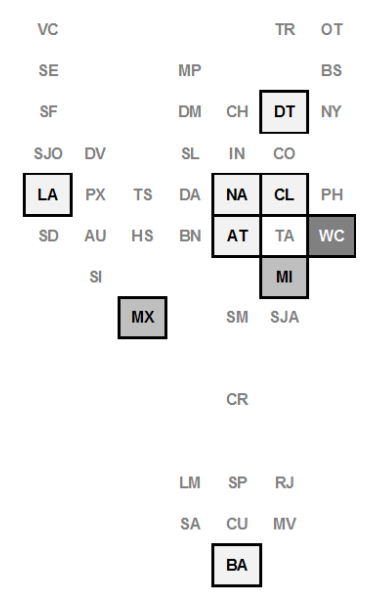

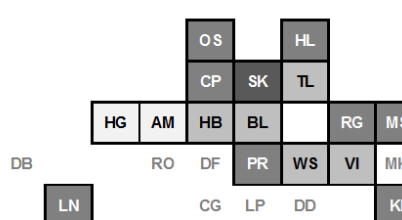

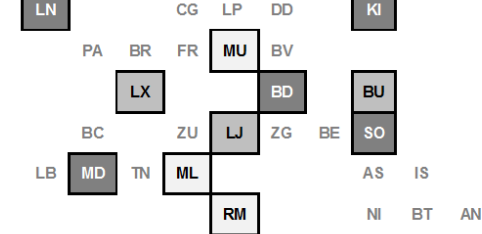

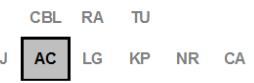

DS

CT JB DR

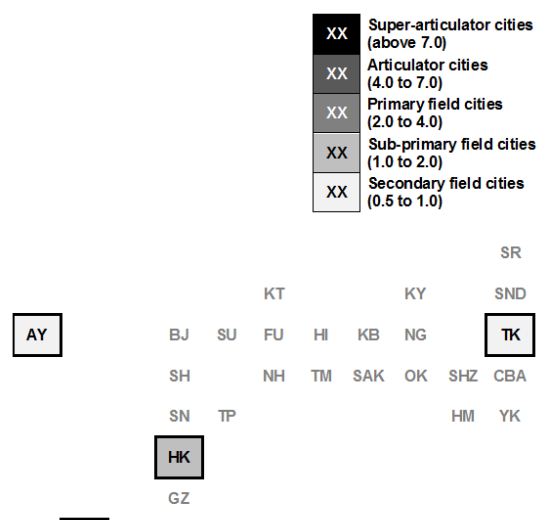

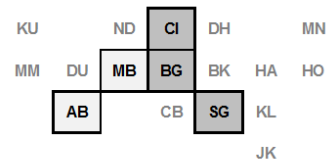

